\title{
NIKAH MUT'AH RIWAYATMU KINI \\ (Tela'ah Tentang Pelaksanaan \\ Sunnah Nikah Mut'ah Melalui \\ Pendekatan Hadits Dan Sirah Nabawiyah)
}

\author{
Uswatun Hasanah \\ Fakultas Ushuluddin \& Pemikiran Islam, UIN Raden Fatah Palembang \\ uswatunhasanah1903@gmail.com
}

\begin{abstract}
This paper concludes that when looking at the history of hadith and sirah nabawiyyah around the legitimacy and the prohibition of marriage mut'ah understood that mut'ah marriage is not a good sunnah to do. This conclusion denied the opinion of al-Thabathabai in particular and the Shi'ite group in general who stated that the Shia still allow and allow the implementation of the Mut'ah marriage in the present. This research supports the opinion of al-Nawawi as an ambassador of the Sunni group who said about the salting of mut'ah marriage
\end{abstract}

Kata kunci: Nikah Mut'ah, legitimasi, pengharaman.

\section{A. PENDAHULUAN}

Apabila berbicara tentang nikah mut'ah biasanya akan terbayang Syiah sebagai kelompok yang banyak mengambil bagian dalam pelaksanaannya, bahkan seolah-olah nikah mut'ah identik dengan ajaran Syiah. Padahal sesungguhnya ajaran tentang nikah mut'ah bukanlah bersumber dari ijtihad pribadi kelompok Syiah. Menurut Syiah atau sekelompok masyarakat yang mempraktekkan nikah mut'ah bahwa nikah mut'ah merupakan bagian dari sunnah Rasul saw. Nikah mut'ah diakui dan dipraktekkan sejak keberadaan

Rasul saw di tengah-tengah sahabatnya. Dengan kata lain pelaksanaan nikah mut'ah menurut para penganutnya berdasarkan dalil al-Qur'an, hadis serta keterangan-keterangan dalam sirah nabawiyah.

Sebagai ummat Nabi
Muhammad saw tentu akan
mengalami kerugian yang sangat
besar jika meninggalkan satu
kesempatan melaksanakan sunnah
yang mudah atau bahkan disukai
terutama bagi kaum laki-laki.
Karena umumnya yang akan lebih
banyak mendapatkan manfa'at dari
pelaksanaan nikah mut'ah adalah


Uswatun Hasanah; Nikah Mut'ah Riwayatumu kini (Tela'ah Tentang Pelaksanaan Sunnah Nikah Mut'ah Melalui Pendekatan Hadits dan Sirah Nabawiyah)

laki-laki. Kebenaran syariat dari Rasul saw yang dijadikan landasan tentang legitimasi atau bahkan anjuran (sunnah) untuk melakukan nikah mut'ah perlu ditelusuri agar sedapat mungkin menemukan banyak jalan guna mendekatkan diri kepada Rasul saw (mengikuti sunnah). Sebaliknya apabila tradisi ini bukan berasal dari Rasulullah saw atau pernah ada tetapi sudah dihapuskan pemberlakuannya maka bersegera untuk meniadakan pengamalannya.

Tulisan ini akan membahas kontroversi seputar nikah mut'ah antara kebolehan dan pelarangannya berdasarkan analisa terhadap hadis-hadis Rasul saw dan sirah nabawiyah yang tentu saja didukung oleh ayat-ayat al-Qur'an dan pendapat ulama.

\section{B. PEMBAHASAN}

\section{Hadis-Hadis Nikah Mut'ah}

Hadis-hadis yang membahas tentang pelaksanaan nikah mut'ah dibagi menjadi dua kelompok yaitu hadis-hadis yang membolehkan dan hadis-hadis yang melarang.

Hadis-hadis yang membolehkan.

\section{1. riwayat Ibn Abbas}

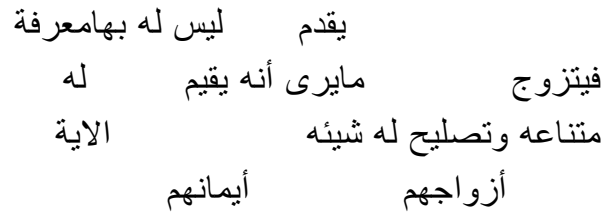

هدين فهو

Dari Ibn Abbas, ia berkata bahwa: nikah mut'ah pada awal Islam adalah seorang yang datang di sebuah negeri muslim yang tidak ia kenal, maka orang tersebut mengawini wanita dengan harapan ia bisa bermukim dan wanita itu dapat menjaga keamanan hartanya dan menjaga kehormatannya hingga turun ayat kecuali istri-istri mereka atau tangan kanan mereka. (Q.S al-Mu'minun (21): 6) Ibn Abbas berkata: setelah turun ayat tersebut semua hubungan selain yang dua itu haram. (Abu Isa; 1980)

\section{Riwayat Muslim al-Qurri}

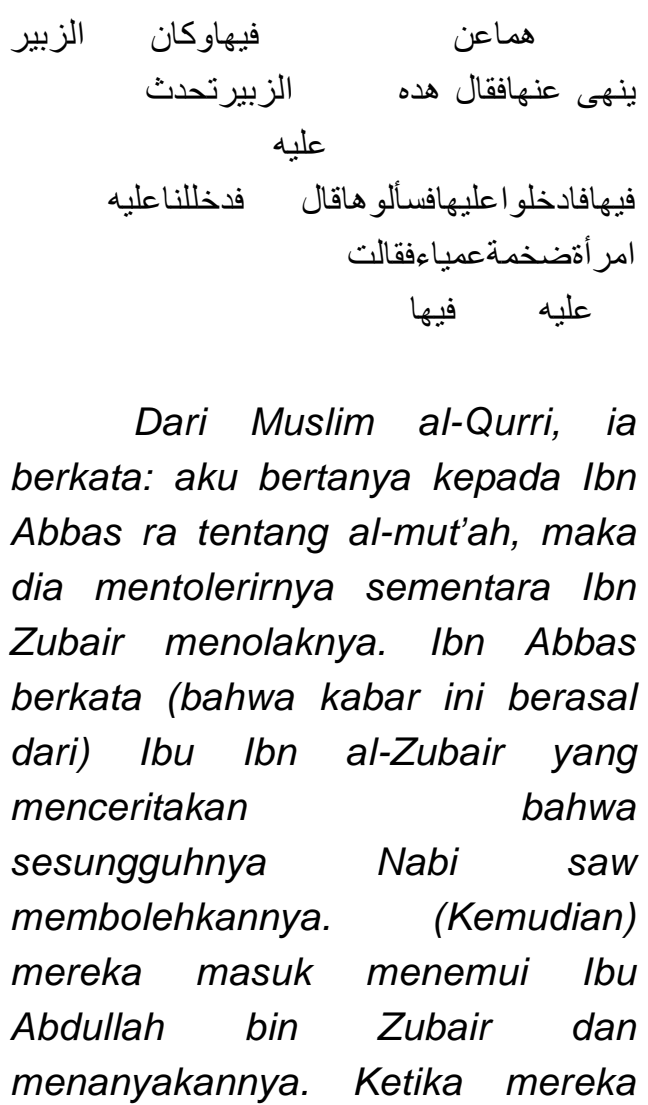


masuk bertemu dengan seorang perempuan gemuk dan sudah tidak dapat melihat lagi (Ibu Abdullah bin Zubair yang sudah tua), (maka perempuan itu) berkata (bahwa) Rasulullah saw telah membolehkannya. (Abu Husain; 1985)

\section{Hadis-hadis yang melarang.}

\section{Pada Perang Khaibar (7 H)}

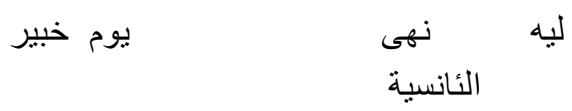

Dari Ali bin Abi Thalib (berkata bahwa): sesungguhnya Rasulullah saw melarang nikah mut'ah pada hari Khaibar dan (juga) memakan daging Khimar local. (Abu Husain; 1985)

\section{Pada Perang Awthas ( $10 \mathrm{H}$ )}

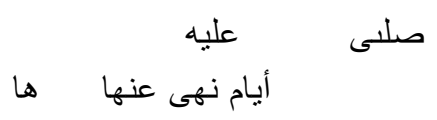

Dari Salamah al-Akwa'i ia berkata (bahwa): Nabi saw membolehkan nikah mut'ah pada perang Awtas selama tiga hari kemudian melarangnya (Muslim; 1379)

\section{Pada Waktu Umrah al-Qadah} ( 7 H)

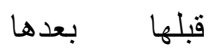

Abd al-Razaq (berkata bahwa telah berkata padanya) dari Ma'mar dan al-Hasan, keduanya berkata (bahwa) nikah mut'ah tidak dihalalkan kecuali hanya tiga hari pada Umrah al-Qada'i dan tidak pernah dibolehkan sebelum dan sesudahnya.( Al-Sayyid; 1404H)

\section{Pada am al-Fath (8 H).}

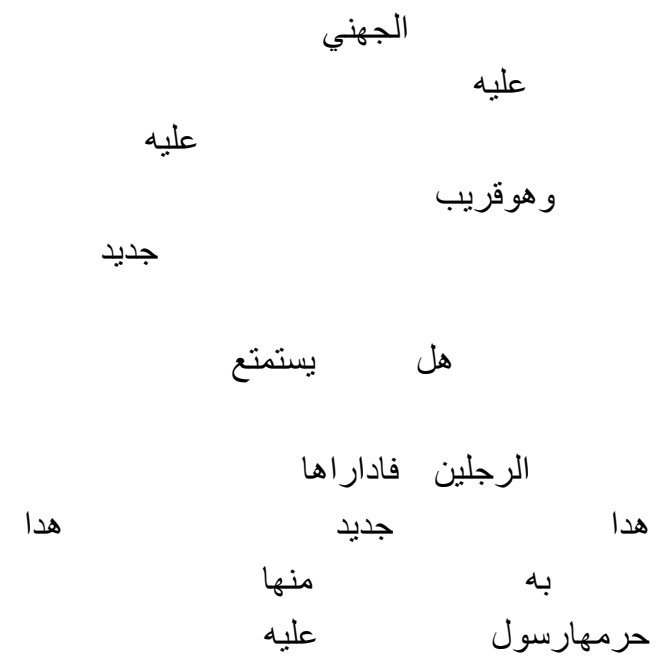

Nabi saw mengizinkan kami pada tahun Fath $\}$ al-Makkah melaksanakan nikah mut'ah. Saya keluar bersama seorang sahabat dari kaumku. Aku memiliki ketampanan yang lebih dibandingkan dia dan masingmasing kami memiliki selendang. Selendang aku sudah tua sedangkan selendang anak pamanku baru. Ketika kami berada di puncak kota Mekkah kami bertemu seorang perempuan tinggi semampai dan lincah. Kemudian kami bertanya kepadanya apakah dia siap nikah mut'ah dengan salah seorang di antara kami. Tiba-tiba ia 
Uswatun Hasanah; Nikah Mut'ah Riwayatumu kini (Tela'ah Tentang Pelaksanaan Sunnah Nikah Mut'ah Melalui Pendekatan Hadits dan Sirah Nabawiyah)

memandang sahabatku, kemudian sahabatku berkata burdah ini sudah tua (sambil menunjuk ke arah burdahku) sedangkan burdahku masih baru (sambil menunjukkan burdahnya). Lalu perempuan itu berkata, burdah ini tidak apa-apa (cukup lumayan sambil menunjuk burdahku), dan mengulanginya. Selanjutnya aku nikah mut'ah dengannya namun sebelum batas waktunya selesai Rasul saw mengharamkannya. (Muslim;1379)

\section{Pada Perang Hunain ( 8 H),}

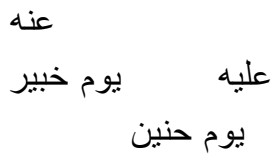

bin Abi Talib berkata (bahwa) Rasulullah saw melarang kami pada perang Khaibar nikah mut'ah, berkata Ibn al-Muthanna pada perang Hunain. (Abu Abd, 1980)

\section{Pada Perang Tabuk ( 9 H).}

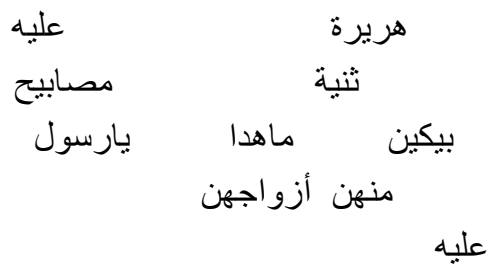

Dari Abu Hurairah (berkata bahwa) kami keluar bersama dengan Rasul saw pada perang Tabuk dan kami singgah di sebuah tempat yang disebut Thaniyati alWada'i maka Nabi saw mendengar tangisan para perempuan. Nabi bertanya siapa para perempuan itu? (Kami menjawab) mereka itu adalah perempuan-perempuan yang telah kami mut'ahkan. Kemudian Rasulullah saw menjawab nikah mut'ah telah diharamkan.(Ibn Hibban)

\section{Pada Haji Wada' (10 H).}

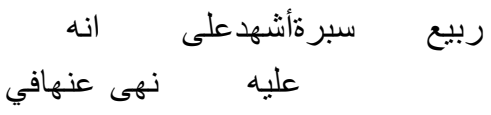

Rabi' bin Sabrah bersaksi atas bapakku (bahwa) sesungguhnya ia telah mendengar Rasulullah saw melarang nikah mut'ah pada haji Wada'(Abu daud; 1988)

\section{Pelarangan tanpa menyebut tempat dan waktu.}

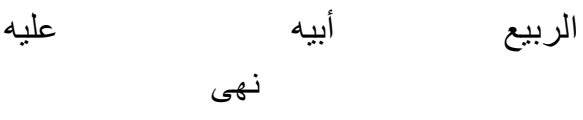

Dari al-Rabi' bin Sabrah dari bapaknya (bahwa) sesungguhnya Nabi saw telah melarang nikah mut'ah.

\section{Il. Kualitas Sanad Hadis}

Ditinjau dari aspek kualitas sanad hadis riwayat Ibn Abbas (w $96 \mathrm{H}$ ) adalah daif. Ibn Hajar (773$852 \mathrm{H})$ mend\}aifkannya dan menghukuminya sebagai hadis shadh karena menurutnya sanad hadis ini kontradiktif dengan riwayat yang lebih kuat. Riwayat 
hadis yang seolah menjadi sebab turunnya ayat al-Qur'an surat alMu'minun (21): 6, semakin menambah nilai d\}aif di mata para ulama hadis. Karena ayat tersebut adalah bagian dari surat alMakiyyah, sementara nikah mut'ah lebih banyak dilaksanakan setelahnya (di Madinah)'. Hadis pembolehan nikah mut'ah lainnya melalui riwayat Muslim al-Qurri misalnya selain terkompilasi dalam Sahih Muslim juga terdapat dalam Sunan al-Kubra al-Baihaqi, Musnad Ah\}mad bin Hanbal dan Musnad alKabir. Adapun sanad riwayat Muslim al-Qurri tidak memiliki masalah sehingga kualitasnya adalah sahih.

$$
\text { Hadis-hadis }
$$

tentang

pelarangan nikah mut'ah di Khaibar $(7 \mathrm{H})$ semuanya diriwayatkan dari Ali bin Abi Talib, ia sebagai sanad terakhir dan perawi pertama tanpa ada shawahid. Dalam kutub alSittah ada lima kitab yang meriwayatkan hadis ini. Empat buah hadis dalam Sahih alBukhari, empat buah hadis dalam Sahih Muslim, lima buah hadis dalam Sunan al-Nasa'i, dua buah hadis dalam Sunan al-Turmudzi dan satu buah hadis dalam Sunan Ibn Madjah. Selain itu hadis ini juga diriwayatkan oleh Malik, Abdu al-Razaq al-San'ani, Ibn Abi Shaibah, al-Darimi, Musnad alHumaid, Sunan al-Baihaqi dan Tarikh al-Baghdadi. Pada level pertama sampai keempat tidak ada perbedaan sumber riwayat kecuali dalam Tarikh al-Baghdadi yang meriwayatkan hadis dengan jalur periwayatan dari Malik, al-Zuhri dari Abdullah secara menyendiri tanpa menyebut al-H\}asan (kemudian dari bapaknya Ali bin Abi Talib) seperti riwayat lainnya (Abu Abdullah) Namun demikian berkaitan degan kualitas sanad hadis tersbut ulama hampir sepakat atas kesahihannya.

Selain informasi pelarangan nikah mut'ah pada perang Khaibar (7 H) sebagaimana yang dijelaskan sebelumnya bahwa terdapat versi lain tentang waktu pelarangan nikah mut'ah yaitu: pada perang Awtas $(10 \mathrm{H})$, pada waktu Umrah al-Qadai $(7 \mathrm{H})$, pada 'Am al-Fath (8 $\mathrm{H}$ ), perang Hunain (Syawal $8 \mathrm{H}$ ), perang Tabuk $(9 \mathrm{H})$, Haji Wada' (10 H) serta pelarangan tanpa menyebut tempat dan waktu. Adapun mengenai kualitas masingmasing hadis adalah sebagai berikut: pertama pelarangan nikah Mut'ah pada perang Awtas (10 H). Perawi hadis pada tingkat sahabat terpusat pada Salamah bin 'Amr bin al-Akwa' al-Aslami (w $74 \mathrm{H}$ ). la termasuk sahabat yang ikut dalam Bait al-Ridwan. Dari verifikasi kualitas sanad hadis tidak seorang perawi pun yang dikritik oleh para kritikus hadis. Karena itu sanad hadis ini disimpulkan berkualitas sahih.

Kedua, riwayat tentang pelarangan nikah mut'ah pada 
Uswatun Hasanah; Nikah Mut'ah Riwayatumu kini (Tela'ah Tentang Pelaksanaan Sunnah Nikah Mut'ah Melalui Pendekatan Hadits dan Sirah Nabawiyah)

waktu Umrah al-Qada'i (7 H). Hadis diriwayatkan dari Hasan bin 'Ali bin Abi Talib dengan sanad yang mursal. Secara umum Ibn Hajar menilai al-Hasan sebagai perawi thiqah, faqih, mashhur akan tetapi banyak meriwayatkan hadis secara mursal dan banyak pula melakukan tadlis. "i Meskipun didapati hadis lain sebagai shahidiii namun semua sanad bermuara kepada Hasan sendiri. Karena itu muhaddis menghukumi sanad hadis Hasan berkualitas d\}aif. Adapun yang ketiga, riwayat larangan nikah mut'ah pada Am al-Fath pada tahun $8 \mathrm{H}$. Sanad hadis selain diriwayatkan dalam banyak jalan seperti Muslim, Abd al-Razaq, alBaihaqi dan Ahmad bin Hanbal, tidak seorang perawi pun dalam sanad yang dinilai daif. Karena itu sanad hadis riwayat ini berkualitas tidak sahih.

Keempat, pelarangan nikah mut'ah pada perang Hunain di bulan Syawal tahun $8 \mathrm{H}$. Hadis diriwayatkan oleh al-Nasa'i dalam sunannya sedangkan Ali sebagai sanad terakhir. Hadis tersebut tidak memiliki shawahid dan mutabi'. Ibn Hajar menilainya tashif pada lafal Khaibar. Menurut al-Daruquthni terdapat Abd al-Wahhab yang menyendiri dalam riwayatnya ${ }^{i v}$, karena itu hadis riwayat al-Nasa'i ini sanadnya disimpulkan berkualitas daif.

Kelima, pelarangan nikah mut'ah pada perang Tabuk di tahun
$9 \mathrm{H}$. Terdapatnya seorang perawi bernama Muammal bin Isma'il dalam sanadnya, yaitu seorang perawi yang banyak dinilai daif oleh para kritikus hadis, menjadikan sanad hadis ini pun berkualitas daif. Abu Hatim menilainya saduq namun banyak keliru. Bukhari menilainya sebagai munkaru al-hadith dan Ibn Hajar menilainya saduq namun jelek hafalannyav. Karena itu riwayat ini dikatakan berkualitas daif.

Keenam, nikah mut'ah pada haji Wada pada tahun $10 \mathrm{H}$. Kualitas hadis diperdebatkan. Alasan kritikus hadis melemahkannya karena seharusnya hadis ini tidak hanya diriwayatkan oleh Rabi' bin Sabrah saja tetapi oleh mayoritas sahabat yang turut hadir dalam haji Wada'. Ibn Hajar memandang ada kemungkinan terjadi kekeliruan mengenai penyebutan Fath alMakkah dan haji Wada' vi Ketujuh, riwayat pelarangan tanpa menyebut tempat dan waktu. Tidak seorang perawi pun yang dipermasalahkan dalam sanad ini. Karena itu kualitas sanad adalah sahih.

\section{Kualitas Matan Hadis}

Riwayat Ibn Abbas apabila ditinjau dari kualitas matan hadis menurut ulama hadis kontradiktif dengan hadis yang kualitasnya lebih sahih dan diriwayatkan juga dari Ibn Abbas melalui al-Bukharivii. 
Ulama juga menolak bahwa keberadaan surat al-Mu'minun (21) ayat 6 telah memansukh praktek nikah mut'ah karena ayat ini tergolong ayat Makiyah yang turun pada periode pertama Islam. Padahal praktek nikah mut'ah adalah legal dan konstitusional pada periode Madinah ${ }^{\text {viii }}$ Namun apabila melihat banyaknya riwayat pembolehan dan pelarangan dalam berbagai versinya. Yang mengidentifikasikan bahwa pembolehan dan pelarangan tidak terjadi satu kali saja maka riwayat Ibn Abbas ini bisa diterima.

Hadis pembolehan lainnya melalui riwayat Muslim al-Qurri pun terdapat permasalahan pada substansi hadis yaitu pada lafal mut'ah yang dinilai kontroversial. Secara ekplisit hadis menyebutkan bahwa Muslim al-Qurri menanyakan kepada Ibn Abbas tentang mut'ah al-hajj dan pada riwayat lain disebutkan mut'ah saja tanpa mengaitkan al-hajj atau alnisai. Muslim, Ahmad dan lainnya mengklasifikasikan hadis riwayat Muslim al-Qurri pada kitab al-hajj bukan pada kitab al-nikah al-mut'ah sebagai isyarat bahwa maksud lafal al'mut'ah yang dipahami dalam hadis adalah mut'ah al-hajj bukan mut'ah al-nisa'i. Berbeda dengan al-Tabatabai dalam tafsirnya ia menukil hadis riwayat Muslim al-Qurri dengan mencantumkan lafal al-mut'ah saja. ${ }^{i x}$ Pemahaman al-Tabatabai dalam riwayat bahwa maksud penanya adalah nikah mut'ah bukan mut'ah haji. Al-Tabatabai mengabaikan riwayat lainnya dan memilih riwayat yang menyebut mut'ah al-nisa'i sebagai dasar legalnya nikah mut'ah pada zaman Nabi saw. Pendapat al-Tabatabai ini semakin kuat apabila melihat matan di akhir hadis. Pada matan hadis jelas tergambar adanya konfirmasi tentang legitimasi nikah mut'ah dengan seorang ibu Abdullah bin Zubair. Sebagaimana diketahui dalam sirah alnabawiyyah bahwa ibu Abdullah bin Zubair yaitu Asma' binti Abu Bakar pelaku nikah mut'ah. Bahkan atas pernikahan mut'ahnya dengan Zubair bin Awwam, Asma' binti Abu Bakar mendapat dua orang putra yaitu Abdullah bin al-Zubair sendiri sebagai sahabat yang mengkonfirmasi hadis dan Urwah bin al-Zubair saudaranya.

Adapun kualitas matan hadis tentang pelarangan nikah mut'ah di Khaibar $(7 \mathrm{H})$ berbeda ulama dalam menyikapinya. Hal ini disebabkan oleh perbedaan dalam memahami matan atau konten hadis. Dalam Musnad al-Humaid (448 H), Sufyan bin 'Uyainah (w $198 \mathrm{H}$ ) berkata bahwa al-Zuhri (w $123 \mathrm{H} / 125 \mathrm{H})$ memberitahukan kepadanya bahwa Ali telah berkata kepada Ibn Abbas (w 96 H). Ibn Abbas berkata bahwa Rasul saw telah melarang makan daging 
Uswatun Hasanah; Nikah Mut'ah Riwayatumu kini (Tela'ah Tentang Pelaksanaan Sunnah Nikah Mut'ah Melalui Pendekatan Hadits dan Sirah Nabawiyah)

Khimar lokal dan nikah mut'ah di Khaibar. Ibn Uyainah (w 198 H) memahami bahwa yang dilarang Rasul saw di Khaibar hanya memakan daging Khimar tidak termasuk praktek nikah mut'ah. pelarangannya baru menyusul kemudian.

Al-Baihaqi mengomentari riwayat al-Humaid (w $448 \mathrm{H}$ ) dan menurutnya Sufyan adalah seorang yang muhtamal. Sumber utama perbedaan ini sebenarnya hanya bermuara dari mana penyebutan lafal yang lebih dulu, yaitu khimar lebih dahulu ataukah mut'ah yang lebih dahulu. Pada lafal al-Zuhri tidak seperti apa yang terdapat dalam riwayat Malik (w 179 H). Pendapat Ibn Uyainah (w $198 \mathrm{H}$ ) didukung oleh pendapat Ibn Qayyim (691 H-751 H), menurutnya bahwa pelarangan Rasulullah saw di Khaibar $(7 \mathrm{H})$ hanyalah terhadap daging Khimar lokal saja. ${ }^{x}$

\section{Terdapat permasalahan} pada kualitas matan hadis pelarangan nikah mut'ah pada waktu perang Awtas $(10 \mathrm{H})$. Di satu sisi perawi hadis menyatakan 'Am Awtas (tahun Awtas) bukan di Awtas, maka boleh jadi yang dimaksud adalah Fath al-Makkah bukan pada perang 'Awtas. Menurut muhaddis pengungkapan kata perang 'Awtas lebih mudah diingat daripada Fath al-Makkah. Sedangkan menurut Abu Hatim perang 'Awtas dan Fath al-Makkah adalah satu. ${ }^{\mathrm{xi}}$ Pelarangan pada waktu Umrah al-Qadai $(7 \mathrm{H})$, kualitas matan hadisnya menurut muhaddis adalah lemah disebabkan sanadnya lemah. Hadisnya pun dianggap sebagai suatu yang tidak bisa dijadikan dalil untuk berhujjah.

Adapun palarangan nikah mut'ah pada 'Am al-Fath $(8 \mathrm{H})$ tidak terdapat permasalahan di seputar sanad dan matan hadis. Karena itu riwayat ini dianggap sahih dari segi sanad dan matannya. Ibn Hajar menilai hadis tentang pelarangan nikah mut'ah pada perang Hunain (Syawal $8 \mathrm{H}$ ) tashif pada kata Khaibar. Menurut al-Daruqut\{ni bahwa Abd al-Wahhab menyendiri dalam periwayatan hadisnya, yang seharusnya ia riwayatkan adalah Khaibarii. Dengan demikian disimpulkan hadis ini kualitasnya lemah dan tidak bisa dijadikan rujukan sebagai dalil pelarangan nikah mut'ah.

Sedangkan pelarangan nikah mut'ah pada perang Tabuk ( 9 $\mathrm{H})$, ulama menilai kualitas matan hadis ini daif karena sanadnya yang lemah dan tidak bisa dijadikan hujjah. Demikian pula pelarangan pada waktu haji Wada' $(10 \mathrm{H})$, kualitas hadisnya lemah, karena memiliki sanad yang lemah, sebagian ulama menjarh dan adapula yang mendaifkannya. Dalam riwayat tentang pelarangan tanpa menyebut tempat dan waktu tidak memiliki masalah dalam sanad dan matan, sehingga hadis 
ini dapat disebut sebagai berkualitas sahih.

\section{Asbab al-Wurud}

Beberapa asbab al-wurud hadis bisa diketahui melalui sanad hadis, tidak terkecuali hadis-hadis tentang legitimasi dan pelarangan nikah mut'ah asbab al-wurudnya dapat diketahui melalui sanad hadis. Sebagaimana riwayat Ibn Abbas dijelaskan dalam sanad bahwa pada masa awal Islam ketika seorang datang di sebuah negeri yang tidak ia kenal. Maka orang itu mengawini seorang wanita dengan harapan ia bisa bermukim dan wanita tersebut bisa menjaga kemananan hartanya dan juga kehormatannya, kemudian turunlah surat al-Mu'minun (21) ayat $6{ }^{\text {xiii }}$ Demikian juga riwayat Muslim al-Qurri, asbab al-wurud dapat dilihat pada sanad hadis, yaitu disebabkan pertayaan seorang sahabat kepada Ibn Abbas. ${ }^{\text {xiv }}$

Adapun asbab al-wurud hadis tentang pelarangan nikah mut'ah masing-masingnya adalah: pertama riwayat pelarangan dalam perang Khaibar, terlepas ada atau tidaknya penyebutan secara tegas tentang pelarangan pada perang Khaibar. Melalui asbab al-wurud dipahami bahwa pelarangan yang diberlakukan Nabi saw pada peristiwa perang Khaibar merupakan aturan untuk mengontrol prilaku kaum muslimin.
Perang Khaibar yang terjadi pada bulan Muharram tahun $7 \mathrm{H}$ dipimpin oleh Ali bin Abi T\}alib dengan membawa seribu empat ratus orang tentara Islam berhasil memenangkan pertempuran setelah terlebih dahulu gagal dua kali di bawah pimpinan Abu Bakar dan Umar bin khatab. ${ }^{\mathrm{xv}}$ Rasul saw sangat memahami kondisi suka cita para sahabat setelah berhasil memenangkan pertempuran, mendapatkan banyak ghanimah dan menjumpai banyak tawanan perempuan. Rasul saw pun tidak menafikkan kerinduan para sahabat terhadap keluarganya yang telah lama terpisah jauh. Kesempatan ini justru dipergunakan oleh Nabi saw untuk mengontrol perilaku para sahabat yaitu dengan melarang pelaksanaan nikah mut'ah. Para perempuan tawanan perang yang berstatus sebagai budak-budak perang dipandang cukup untuk melebur rasa rindu para pejuang terhadap keluarganya.

Kedua, larangan pelaksanaan nikah mut'ah di Awtas, asbab al-wurudnya juga tertulis di dalam sanad hadis, yaitu: ketika suatu masa Rasul saw mengutus pasukan ke Awtas kemudian terjadi perang Hunain. Perang ini pada akhirnya dimenangkan kaum muslimin sehingga mereka banyak memperoleh tawanan. Sebagian sahabat keluar dari kemah untuk 
Uswatun Hasanah; Nikah Mut'ah Riwayatumu kini (Tela'ah Tentang Pelaksanaan Sunnah Nikah Mut'ah Melalui Pendekatan Hadits dan Sirah Nabawiyah)

melakukan nikah mut'ah bersama perempuan musyrik, maka bersabda Rasul saw tentang pelarangan nikah mut'ah. .vi $^{\text {xi }}$ Substansi hadis adalah mendeskripsikan bahwa sesungguhnya Rasul saw telah membolehkan nikah mut'ah pada perang Awtas selama tiga hari namun setelah itu Rasul saw melarangnya. Bisa saja sebab utama pelarangan ini adalah prilaku para sahabat yang menikahi para perempuan musyrik.

Keempat, pelarangan nikah mut'ah bertepatan dengan peristiwa Umrah al-Qada'i. Umrah al-Qada'i terjadi pada bulan Dzul Qaddah bersamaan dengan tahun perang Khaibar $\left(\begin{array}{lll}7 & H\end{array}\right)$. Jumlah kaum muslimin yang ikut serta melakukan Umrah al-Qada'i sekitar dua ribu orang selain perempuan dan anak-anak. Nabi saw beserta para sahabatnya menetap selama tiga hari di Mekkah. Pada pelaksanaan umrah yang cukup singkat ini seorang janda yang masih berumur 26 tahun telah ditinggal oleh suaminya menghibahkan diri kepada Rasul saw lewat perantara Ummu Fad\}al istri Ibn Abbas. Akhirnya Nabi saw menikahi Maimunah binti al-Harits tersebut dengan mahar 500 Dirham, kemudian membawanya serta ke Mekkah berkumpul bersama para istri Rasul saw lainnya. Maimunah binti al-Harits tercatat sebagai wanita terakhir yang dinikahi Rasul saw. ${ }^{\text {xvi }}$ Kemudian Ibn Abbas meriwayatkan hadis pelarangan nikah mut'ah atas peristiwa tersebut.

Kelima, dalam riwayat Muslim dijelaskan tentang adanya pelarangan nikah mut'ah pada waktu peristiwa Fath al-Makkah. Asbab al-wurud hadis dapat dilihat pada sanad hadis itu sendiri. Dikisahkan oleh Rabi' bin Sabrah bahwa Nabi saw mengizinkan untuk nikah mut'ah pada tahun Fath al-Makkah. Suatu waktu Rabi' dan sahabatnya keluar rumah dan melakukan perjalanan. Rabi memiliki wajah yang lebih tampan dibandingkan sahabatnya. Masingmasing dari keduanya pergi dengan membawa selendang. Ketika sampai di kota Mekkah, mereka bertemu dengan seorang perempuan berpostur tinggi semampai dan lincah. Keduanya bertanya kepada perempuan tersebut tentang kesediaannya untuk nikah mut'ah dengan salah satu di antara mereka. Singkat cerita kemudian Rabi' menikahi secara mut'ah perempuan tersebut, namun sebelum batas waktu selesai Rasul saw telah mengharamkannya. ${ }^{\text {xviii }}$

Keenam, pelarangan nikah mut'ah pada peristiwa perang Hunain (Syawal $8 \mathrm{H}$ ) Ali bin Abi Talib sebagai sanad pertamanya. Perang Hunain terjadi pada bulan Syawal tahun $8 \mathrm{H}$ di sebuah lembah $37 \mathrm{~km}$ dari kota Mekkah. 
Diriwayatkan dari Ibn Muthanna bahwa Rasul saw telah melarang nikah mut'ah pada peristiwa ini. ${ }^{\text {xix }}$ Riwayat ketujuh adalah pelarangan nikah mut'ah pada peristiwa perang Tabuk tahun $9 \mathrm{H}$. Sebagaimana riwayat lainnya bahwa asbab alwurud hadis dapat diketahui pada sanad hadis. Diceritakan dari Abu Hurairah bahwa ia keluar bersama Rasul saw pada perang Tabuk. Perang Tabuk disebut juga dengan perang dalam kesulitan sebab situasinya sedang dalam penderitaan, paceklik dan suasana yang panas luar biasa. Mereka singgah di suatu tempat yang disebut Taniyati al-Wada'i maka Rasul saw mendengar tangisan para perempuan, lalu Rasul saw bertanya siapakah para perempuan itu? Mereka itu ialah perempuanperempuan yang telah kami mut'ahkan. Kemudian Rasulullah saw menjawab: nikah mut'ah telah diharamkan. $^{\mathrm{xx}}$

Ketujuh, pelarangan nikah mut'ah pada Haji Wada' tahun 10 H. Haji Wada' merupakan haji perpisahan terjadi pada tahun ke 10 H. Pada haji Wada' inilah Rasul saw berkhutbah di Arapah tepatnya pada tanggal 9 Dzulhijjah di hadapan seratus lima puluh ribu jama'ah. Pada khutbahnya Rasul saw menyampaikan pokok-pokok ajaran agama besarta cabangcabangnya, termasuk juga tentang pengharaman nikah mut'ah. ${ }^{\text {xxi }}$ Rasul wafat di 12 Rabi al-Awwal tahun $10 \mathrm{H}$ tidak sampai seratus hari dari pelaksanaan haji Wada'. Adapun pelarangan nikah mut'ah pada riwayat yang tidak menyebutkan secara khusus tempat dan waktu pelarangannya ialah juga tidak dijumpai secara jelas informasi tantang sebabsebab diriwayatkannya hadis tersebut.

\section{Perbedaan Qira'ah Ayat Nikah Mut'ah}

Allah swt berfirman dalam al-Qur'an surat al-Nisa' (4) ayat 24 yaitu:

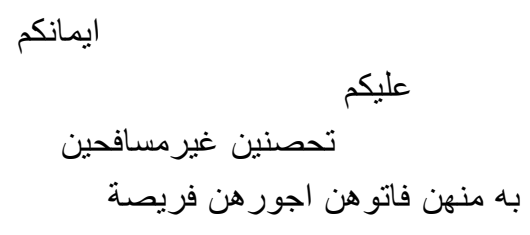

Dan diharamkan juga kamu mengawini wanita yang bersuami kecuali budak-budak yang kamu miliki, (Allah) telah menetapkan hukum itu sebagai ketetapan-Nya atas kamu. Dan dihalalkan bagi kamu selain yang demikian (yaitu) mencari istri-istri dengan hartamu untuk dikawini bukan untuk berzina. Maka istri-istri yang telah kamu ni'mati (campuri) di antara mereka berikanlah kepada mereka maharnya (dengan sempurna) sebagai suatu kewajiban...

Surat al-Nisa' (4) ayat 24 yang menjadi dalil tentang legitimasi nikah mut'ah. Ayat ini memiliki perbedaan dalam qira'ah. ${ }^{\text {xii }}$ 
Uswatun Hasanah; Nikah Mut'ah Riwayatumu kini (Tela'ah Tentang Pelaksanaan Sunnah Nikah Mut'ah Melalui Pendekatan Hadits dan Sirah Nabawiyah)

Riwayat dikeluarkan oleh Abu Hatim dan dinarasikan oleh Ibnu Abbas $^{\text {xxii }}$ menyatakan bahwa ayat تحصنين غيرمسافحين tersebut telah dinasakh dengan

$$
\text { (adapun }
$$

perempuan-perempuan yang kamu mut'ah dengannya sampai pada batas tertentu) ${ }^{\text {xxiv }}$

Pada riwayat yang lain terdapat bentuk qira'ah yang paralel dengan qira'ah Ibn Abbas (w $96 \mathrm{H}$ ), diantaranya qira'ah Ubay bin Ka'ab, Sa'id bin Jabir, al-Sudi dan 'Imran bin al-H\}usain. Imran alHusain berkata bahwa ayat ini turun berkaitan dengan nikah mut'ah dan tidak satu pun ayat yang turun menasakhnya setelah Rasulullah saw wafat. ${ }^{x \times v}$ Riwayat Ubay bin Ka'ab menyatakan: xxvi

به منهن

(Dinarasikan dari Qadatah ia berkata:) Ubay bin Ka'ab membaca ayat (تحصنين غيرمسافحين بهi) dengan bacaan به منهن

(adapun perempuanperempuan yang kamu mut'ah dengannya sampai pada batas waktu tertentu).

Al-Maqdisi ( $\left.\begin{array}{lll}\text { w } & 490 & \mathrm{H}\end{array}\right)$ mengakui qira'ah Ubay bin Ka'ab dan Ibnu Abbas dengan argumentasi bahwa selain tidak ditemukannya koreksian atas qira'ah tersebut dari salah seorang sahabat pun yang hidup sezaman dengan Ibnu Abbas dan Ubay bin Ka'ab. Termasuk tidak ada seorang sahabat pun yang mengklaim bahwa bacaan tersebut tidak masuk sebagai wahyu Allah swt. Meskipun bacaan tersebut tidak terpilih dan tidak masuk ke dalam mushaf di zaman pengumpulan alQur'an ${ }^{\text {xxvii. }}$.

Selain itu qira'ah Ubay bin Ka'ab diperkuat oleh hadis-hadis lain sebagai shawahid dengan sanad berkalitas Hasan riwayat alTabari dan Qatadah melalui Ibnu Abbas. ${ }^{\text {xxviii }}$ Rentetan sanadnya ada Abu Kuraib yaitu Muhammad bin al-'Ula'i bin Karib al-Hamadi, Ibn Hajar menilainya sebagai orang yang thiqah. ${ }^{x x i x}$ Ada pula Yahya bin 'Isa al-Tamimi al-Nashafi, Ibnu Hajar menilainya saduq yukhti. ${ }^{x x x}$ Nasir bin Abi al-Sh'ath al-Asadi dan Abu al-Walid al-Kufi, keduanya dinilai Ibnu H\}ajar thiqah. ${ }^{x \times i}$ Ibnu H\}abib Ibnu Abi Thabit memiliki tiga orang putera, pertama Abdullah, Ibnu H\}ajar menilainya thiqah. Kedua 'Ubaidillah, Ibnu Ma'in menilainya thiqah. Al-Daruquthni menilai ketiga putera Ibnu $\mathrm{H}$ \}abib Ibnu Abi Thabit, baik Abdullah, 'Ubaidillah maupun Abd al-Salam semuanya thiqah. ${ }^{\text {xxii }}$ Ibnu Habib sendiri dinilai berkualitas thiqah, faqih jalil meskipun dinilai banyak melakukan irsal dan tadlis. ${ }^{\text {xxxii }}$ Dengan kualitas sanad hadis yang umumnya dihukumi ta'dil maka disimpulkan berkualitas Hasan.

Al-Tabatbai dan umumnya kaum Syi'ah menjadikan qira'ah Ubay bin Ka'ab dan Ibnu Abbas tersebut sebagai dalil untuk 
memperkuat argumentasi disyariatkannya nikah mut'ah. ${ }^{\text {xxiv }}$ Karena ayat ini berbicara tentang nikah mut'ah maka menurut alTabatabai mas kawinnya disebut dengan ajr yang berarti upah bukan sidaq atau mahr. AlTabatabai juga menolak argumentasi Ahlusunnah dengan alasan terdapat unsur mendeskriditkan dan meragukan kompetensi pemahaman al-Qur'an Ibnu Abbas dan kemampuan tela'ah bahasa Arabnya.

Argumentasi yang diajukan oleh al-Tabatabai tersebut sepertinya tampak logis tetapi apabila dibandingkan dengan ayatayat al-Qur'an sulit untuk diterima. Karena meskipun al-Qur'an menamai mas kawin pernikahan putri Nabi Shu'aib dan Nabi Musa menggunakan istilah ajr ${ }^{x \times x}$ namun pernikahannya bukan dalam bentuk mut'ah.

Al-Tabari $(310 \mathrm{H})$ memiliki pandangan yang berbeda mengenai qira'ah Ubay bin Ka'ab dan Ibnu Abbas, ia memandang bahwa qira'ah tersebut sangat kontradiktif dengan mushaf mayoritas kaum muslimin. Dimana Mayoritas ulama menyikapi qira'ah tersebut sebagai bentuk qira'ah shadhah dan tidak dapat dijadikan hujjah Termasuk tidak layak untuk diamalkan sebab bertolak belakang dengan qira'ah mayoritas Qurra' dan berbeda dengan mushaf yang masyhur ${ }^{\text {xxvi }}$ yaitu tanpa ada tambahan bacaan
Lebih lanjut al-Tabarii menjelaskan bahwa qira'ah Ubay bin Ka'ab dan lbnu Abbas tidak dapat menjadi madlul dan referensi untuk aplikasinya karena qira'ah alQur'an harus berdasarkan dengan dalil yang qat'i. ${ }^{\text {xxviii }} \mathrm{Hal}$ senada juga diungkapkan oleh Makki (w 437 H) menurutnya qira'ah harus berdasarkan kepada riwayat yang Mutawatir bukan Ahad. Nashr bin Ibrahim al-Maqdisi (w $490 \quad \mathrm{H}$ ) memverifikasikan bahwa tambahan bacaan setelah kata bukanlah merupakan ayat al-Qur'an dan tidak pula berasal dari Allah swt. ${ }^{\text {xxxix }}$ Bacaan ini dikenal sebagai bacaan mudraj yaitu kata-kata yang bukan berasal dari lafal asli ayat al-Qur'an tetapi ditambahkan oleh para sahabat sebagai penjelasan makna.

Mayoritas

ulama

Ahlusunnah memahami kalimat mut'ah pada surat al-Nisa (4): 24 sebagai hubungan pernikahan yang terjadi secara normal yaitu nikah daim. Ajr digunakan pada bentuk pernikahan ini karena penekanannya pada kenikmatan dan kelezatan atas hubungan jasmani yang secara harfiah berarti upah atau imbalan tetapi bukan seperti penyewaan barang lainnya. Selain itu ajr digunakan karena pemberian mas kawin setelah berlangsungnya pernikahan. Istilah ajr pada konteks ini sesuai dengan hadis Nabi saw berikut: 
Uswatun Hasanah; Nikah Mut'ah Riwayatumu kini (Tela'ah Tentang Pelaksanaan Sunnah Nikah Mut'ah Melalui Pendekatan Hadits dan Sirah Nabawiyah)

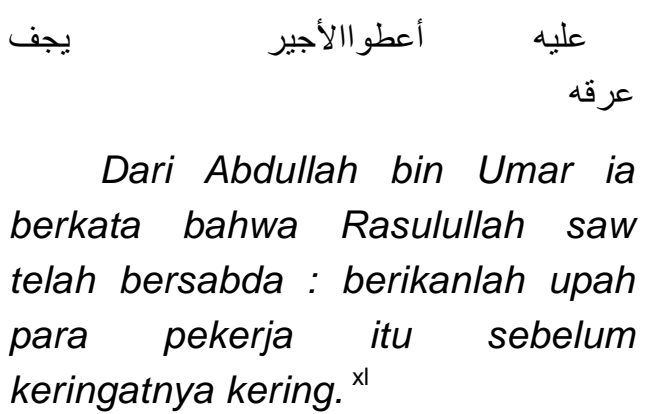

Alternatif pemahaman untuk menjembatani perbedaan pendapat antara Ahlusunnah dan Syiah yang diwakili oleh al-Tabatabai ialah kemungkinan adanya kekeliruan periwayatan ketika mentransmisikan hadis. Karena apabila ditinjau dari aspek kualitas periwayatan, qira'ah Ibnu Abbas berstatus debatable. Dengan kata lain bahwa kualitas periwayatannya tidak sampai ke derajat Mutawatir dan berbeda dengan apa yang termaktub dalam mushaf. AlTabatabai sendiri secara tegas menolak berhujjah dengan hadis yang hanya berkualitas Ahad atau tidak Mutawatir, tetapi untuk riwayat ini kenapa justru alTabatabai menerimanaya bahkan berhujjah dengannya.

Terlepas dari kontradiktif pemahaman terhadap riwayat mengenai substansi hadis disimpulkan bahwa hal ini terjadi karena adanya qira'ah yang bervariatif. Bagi yang memahami kata muhaakkamah dengan maksud mahar bagi istri yang telah digauli maka pemaknaan ini sama dengan pemahaman mayoritas ulama. Sebaliknya bagi yang memahami ayat sebagai ayat nikah mut'ah maka pemahamannya sebagaimana yang dirujuk oleh kelompok Syiah dan minoritas ulama.

\section{Pemahaman Hadis}

\section{Pengertian dan Tata Cara Nikah Mut'ah}

Kata al-Mut'ah merupakan isim masdar dari lafal matta'a. Dengan maddah ini maknanya mengalami perubahan hingga diartikan alintifa'u dan al-talad\}d\}ud\}. Dalam bahasa Arab kata al-mut'ah juga diartikan segala sesuatu yang bermanfaat, kata kerja istamta'a yang berarti mengambil manfaat. Meskipun kata mut'ah memiliki arti yang berbeda-beda namun pada akhirnya mengacu kepada pengertian al-intifa'u . Lafal alistimta'u atau al-tamata'u berikut pecahannya termasuk lafal almushtarak al-lafzi, al-wujuh alnazair atau polisemi, dalam pengertian tidak selamanya paralel dengan makna al-nikah. ${ }^{\text {xli }}$

Al-Istimta'u ditinjau dari aspek filologi berarti al-intifa'u yaitu mencari dan mengharap manfaat dan kelezatan. Setiap yang dimanfaatkan disebut mata'un. Apabila ditinjau syariat lafal almut'ah meliputi tiga hal yaitu: mut'ah haji, mut'ah al-talaq dan mut'ah al-nisa'i (nikah mut'ah). ${ }^{\text {xlii }}$

$$
\text { Al-Tabatabai menegaskan }
$$
bahwa istilah nikah mut'ah dan 
pengaplikasiannya pada komunitas sahabat Nabi saw cukup populer dan sulit dipungkiri atau ditolak adanya. Istilah mut'ah tidak dapat dipahami dari aspek atau makna kebahasaan sebagaimana kata haji, riba, atau ghanimah yang juga tidak bisa dipahami dalam arti kebahasaan. Al-T\}abat\}aba'i dan para ulama Syi'ah memahami kalimat mut'ah pada penggalan dan potongan ayat surat al-Nisa' (4) : 24 menjadi petunjuk bahwa maksud maknanya adalah nikah mut'ah. Sebaliknya mayoritas ulama Ahlu Sunnah memahaminya secara diferensial dengan Syi'ah dalam arti hubungan pernikahan yang tercipta secara normal yaitu nikah daim bukan nikah secara mut'ah.

Pendapat al-Tabatabai tersebut dikuatkan dengan merujuk qira'ah dari beberapa sahabat seperti Ibnu Abbas dari Ubay bin Ka'ab dengan penambahan kata yang berarti batas waktu tertentu setelah kata به sنهن sebagaimana yang dijelaskan pada sub bab sebelumnya. Akan tetapi apabila ditelusuri referensi Syi'ah maka qira'ah (bacaan) pada kalimat به بهن berikut tambahannya terjadi deviasi bacaan atau inkonsisten. Di mana pada sebagian ulama Syi'ah menempatkan lafal

setelah lafal minhunna. Sebagian lainnya menempatkannya setelah lafal ujurahunna. Abu Ja'far sendiri membacanya tanpa lafal sebagaimana ketika alNu'man bertanya kepadanya tentang nikah mut'ah. Dengan demikian bentuk qira'ah ini tidak disepakati oleh kalangan ulama Syiah sendiri sehingga sulit dijadikan sebagai argumentasi untuk mentolerir praktek pelaksanaan nikah mut'ah. Bentuk bacaan ini disebut qira'ah mudraj yaitu kata-kata yang dimaksud bukan merupakan lafal-lafal asli ayat tetapi lafal yang ditambahkan oleh para sahabat yang berfungsi sebagai penjelas makna.

Selain itu al-Tabatabai memahami surat al-Nisa (4) : 4 berbicara tentang nikah mut'ah karena istilah mas kawin yang digunakan adalah ajr yang berarti upah, bukan sidqah atau mahr. Pendapat al-Tabatabai ini selintas sangat ilmiah dan logis namun jika diamati dengan membandingkan ayat-ayat al-Qur'an lainnya, pemahaman ini sulit diterima karena al-Qur'an menyatakan bahwa mas kawin pernikahan putri Nabi Shu'aib dan Nabi Musa menggunakan istilah ajr sebagaimana surat al-Qasas (28): 27, sementara pernikahannya bukan dalam bentuk nikah mut'ah. Dalam al-Quran ditemukan sepuluh macam istilah mas kawin yaitu mahrun, sadaqun atau shadaqah, nihlah, ${ }^{\text {xliii } a j r u n,}$,liv faridah, ${ }^{x / v}$ hibbaun, uqrun, alaiqun, taulun, ${ }^{\text {lvi }}$ dan nikahun. ${ }^{x l v i i}$ Kata ujur adalah lafal 
Uswatun Hasanah; Nikah Mut'ah Riwayatumu kini (Tela'ah Tentang Pelaksanaan Sunnah Nikah Mut'ah Melalui Pendekatan Hadits dan Sirah Nabawiyah)

al-Qur'an yang memiliki makna sinonim termasuk lafal almushtarak al-lafziyah (polisemi) dan khusus pada ayat ini berarti upah, mas kawin atau mahar. Pengertian ini dipahami demikian karena kata ujur dihadapkan dengan lafal al-istimtau maka ia disebut ajran (upah). Selain itu kata ujur mahar diperkuat pada ayat lain surat al-Nisa (4): 24 dan 25, alAhzab (33) : 50, al-Mumtahanah (60) : dan al-Maidah (5) : 3.

Istilah ajr digunakan pada bentuk pernikahan dan kelezatan atas hubungan jasmani yang secara harfiah berarti upah atau imbalan tetapi hakikatnya adalah mahar. Selain itu ajr digunakan karena pemberian mas kawin setelah berlangsungnya pernikahan. Berbeda jika sebelumnya kata ajr dan pengoprasionalannya pada konteks ini sesuai dengan hadis Rasulullah saw. ${ }^{\text {xlviii }}$ Jadi penempatan kata ajr pada ayat sangatlah singkron dan sesuai dengan makna teks kebahasaan dan istilah keagamaan yang dikenal pada ranah kajian stilistika al-Qur'an.

Secara Istilah nikah mut'ah dalam pandangan Ahlusunah dan Syi'ah adalah seorang laki-laki menikahi seorang perempuan sampai batas waktu tertentu dengan memberikan mahar tertentu dan jika batas waktu telah habis maka dengan sendirinya mereka berpisah tanpa talak ataupun cerai, perempuan tersebut harus beristibra (beriddah) sekedar memastikan bersihnya rahim dan tidak berlaku hak waris antara keduanya. xlix Sederhananya nikah mut'ah merupakan pernikahan dengan menyebut batas waktu.

$$
\text { Apabila memperhatikan }
$$

riwayat Ibn Abbas sebelumnya tentang legitimasi nikah mut'ah dan juga riwayat Muslim serta riwayat lainnya tentang pelarangan nikah mut'ah dipahami bahwa pengertian dan tata cara pernikahan ini ialah seorang laki-laki datang kepada seorang wanita (al-Qurt\}ubi mengharuskan adanya wali dan saksi) kemudian mereka membuat kesepakatan mahar (upah) misalnya berupa selendang sebagaimana riwayat Muslim dan batas waktu tertentu misalnya hanya pada waktu perang berlangsung dua hari, tiga hari ataupun kurang. Biasanya tidak lebih dari empat puluh lima hari. Tidak ada nafkah dan tidak saling mewarisi sebagaimana riwayat dimana kondisi pelaksanaan nikah mut'ah adalah medan perang yang tidak memungkinkan untuk memberi nafkah lahir maupun batin kecuali hanya pemenuhan hasrat seksualitas semata dan juga tidak ada kelebihan harta yang bisa diwariskan. Tidak pula ada iddah kecuali istibra (memastikan bersihnya rahim)' karena memang pernikahan ini diniatkan untuk jangka waktu yang tidak lama, 
sekedar pelepas dahaga di kala rasa haus menyekat di tenggorokan.

\section{Hukum dan Hikmah Nikah Mut'ah Pada Masa Rasul saw dan Sahabat.}

Apabila dilihat dari data sejarah keberadaan nikah mut'ah sulit terbantahkan. Terlepas dari sahih atau lemahnya riwayat ataupun berkaitan kapan kepastian dibolehkan dan dilarangnya nikah mut'ah, banyaknya riwayat yang menceritakan tentang nikah mut'ah cukup memberi keyakinan akan keberadaannya. Juga banyak sahabat yang mempraktekkan nikah mut'ah baik pada masa Rasul saw masih hidup atau setelahnya. Para sahabat pelaku nikah mut'ah misalnya: Jabir bin Abd Allah, Abd Allah bin Mas'ud, al-Zubair bin Awwam, Asma binti Abu Bakr, Abdullah bin 'Umar, Mu'awiyyah bin Abi Sufyan, Abu Sa'id al-Khudri, Salmah bin Umayyah bin Khalaf, Ma'bad bin 'Umayyah, Khalid bin Muhajir al-Makhzumi, 'Amr bin Harith, Ubay bin Ka'b, Samurah bin Jundab, Sa'id bin al-Jubair dan Zufar' Dalam sebuah athar juga disebutkan beberapa sahabat yang nikah mut'ah setelah wafatnya Nabi saw seperti: Rabi'ah bin 'Umayyah dan Amr bin al-Harith. ${ }^{1}$ Meskipun Rasul saw tidak melakukan nikah mut'ah namun disepakati bahwa hadis tidak hanya berupa prilaku Nabi saw tetapi juga termasuk perkataan dan taqrirnya atas prilaku para sahabat di sekitarnya. Sebagaimana yang diketahui dari hadis dan sirah nabawiyyah bahwa Rasul saw memberikan respon terhadap prilaku nikah mut'ah sahabatnya, baik dalam bentuk legitimasi ataupun pelarangan.

Melalui asbab al-wurud hadis diketahui bahwa pelaksanaan nikah mut'ah umumnya terjadi di medan perang. Kala itu, mayoritas tentara Islam adalah dari golongan pemuda, yakni pria lajang yang belum sempat mengikat dirinya dengan ikatan benang kasih di bawah atap pernikahan juga para pria muda yang telah memiliki istri namun terpaksa meninggalkan istri-istri mereka untuk pergi berjihad $\mathrm{fi}$ sabilillah. Sebagai manusia biasa, bersama semangat jihadnya di padang pasir untuk menegakkan syiar Islam, rasa rindu terhadap lawan jenis sebagai gejala fitrah insani pun berkobar. Mereka mencoba memasung keinginan jiwanya itu sembari melakukan kontak senjata melawan para tentara musuh, maka dalam kondisi seperti ini puasa bukanlah solusi efektif, karena akan berakibat fisik menjadi lemah. Kondisi inilah yang kemudian mengantar awal disyariatkannya nikah mut'ah. Fakta sejarah ini dibuktikan dengan banyaknya hadis serta sirah nabawiyyah membahas tentang legitimasi dan pelarangan nikah mut'ah di seputar 
Uswatun Hasanah; Nikah Mut'ah Riwayatumu kini (Tela'ah Tentang Pelaksanaan Sunnah Nikah Mut'ah Melalui Pendekatan Hadits dan Sirah Nabawiyah)

medan perang untuk para prajurit yang sedang berperang. Al-Hazimi $(584 \mathrm{H})$ menambahkan bahwa praktek nikah mut'ah pada masa awal Islam adalah mubah secara hukum. Sahabat melakukan nikah mut'ah karena mereka melakukan perjalanan jauh tanpa didampingi oleh para istri mereka. Tidak dalam kondisi aman di rumah atau tidak pula berada di dalam kampung halamannya sendiri. lii

Dari kilas balik sejarah nikah mut'ah, jelas terbaca bahwa disyariatkannya nikah mut'ah hanya pada saat terjadi perang dan dalam perjalanan jauh, yakni di saat para sahabat berpisah dengan keluarga tercinta untuk menunaikan tugas suci, jihad melawan musuh. Seperti pada waktu terjadinya perang Khaibar, Umrah Qadha, perang Authas, Fath al-Makkah, perang Tabuk, dan pada saat Nabi melakukan haji Wada'. Di sanalah mereka diberi keringanan oleh Nabi saw untuk melangsungkan pernikahan dengan penduduk di tempat mereka mempertaruhkan nyawa demi membela agama. Setelah selesai perang maka putuslah tali pernikahan itu karena waktunya telah habis.

Selain itu para muhaddis memandang bahwa kebolehan nikah mut'ah pada masa-masa awal Islam, di mana akidah masyarakat baru saja dibangun di atas tradisi jahiliyah yang gemar kepada zina dan bermain perempuan juga berkaitan dengan kebebasan dan hak terhadap budak ataupun tawanan perang. Sebagai rukhsah karena faktor darurat perang dibolehkannya nikah mut'ah sebagaimana dispensasi bolehnya makan bangkai, darah dan daging babi pada masa yang sangat sulit seperti untuk kepentingan keselamatan dan pengobatan. liii Juga beragam asbab al-wurud yang menginformasikan tempat dan waktu yang berbeda dalam legitimasi dan pelarangan nikah mut'ah dipahami bahwa praktek nikah mut'ah pernah dilegalkan dan diharamkan beberapa kali karena kondisi darurat. liv Dengan kata lain banyaknya riwayat yang menjelaskan tentang pelarangan nikah mut'ah dalam waktu dan tempat yang berbeda-beda memberikan isyarat bahwa pelarangan tidak terjadi satu kali saja, tetapi berulang-ulang. Hal ini juga memberi pengertian bahwa permasalahan nikah mut'ah bukan merupakan perkara yang sepele sehingga tidak cukup apabila hanya satu kali saja diperingatkan.

\section{Nikah Mut'ah di Masa Kini}

Akan halnya praktik pelaksanaan nikah mut'ah saat ini, terjadi silang pendapat antara kebolehan dan pengharamannya. Meskipun keharaman nikah mut'ah 
secara konsensus hampir disepakati oleh kalangan ulama namun tidak sedikit dari ulama khususnya penganut Syi'ah membolehkannya. Riwayat yang disepakati para ulama sebagai dalil pengharamannya antara lain pelarangan nikah mut'ah tepat pada pelaksanaan haji Wada $\mathrm{W}^{\mathrm{lv}}$, juga melalui sebuah athar diketahui bahwa 'Umar bin Khatab dalam sebuah pidatonya pernah berkata:

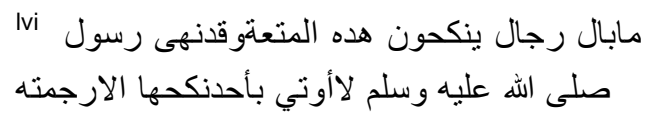

(Ketika Umar bin Khatab naik ke atas mimbar memuji Allah swt dengan berbagai pujian atas-Nya kemudian Umar berkata:) A pa yang menyebabkan mereka melakukan niikah mut'ah ini? Sungguh Rasulullah saw telah melarangnya. Ketahuilah sesungguhnya aku akan menghadirkan para pelaku nikah mut'ah dan aku akan merajamnya.

Begitu banyak kontroversial menanggapi athar pelarangan nikah mut'ah oleh Umar bin Khatab. Khususnya ulama yang tergolong Syiah ataupun Ahlusunah yang masing-masingnya menjadikan dalil tersebut untuk mendukung pendapat mereka. Di satu sisi Ahlusunah memandang athar ini semakin memperkuat bukti keharaman nikah mut'ah. Pelarangan nikah mut'ah yang disebutkan dalam pidato Umar bin
Khatab di hadapan para sahabat dan tabi'in tanpa protes dari siapapun, dipandang sebagai dalil yang otentik atas persetujuan (ijma') pengharaman nikah mut'ah. Sebaliknya di sisi lain Syiah menganggap athar ini hanya merupakan ijtihad Umar bin Khatab semata ketika ia menjabat sebagai seorang khalifah, sementara Rasul saw tidak pernah mengharamkannya. ${ }^{\text {Ivii }}$

Senada dengan pendapat Syiah, al-Tabatabai sebagai tokoh dari kalangan Syiah menyebutkan bahwa keputusan Umar bin khatab atas pengharaman nikah mut'ah di akhir kekhalifahannya, bukanlah larangan berdasarkan pada hukum agama. Akan tetapi sama seperti pertimbangan kemaslahatan lainnya yang senantiasa dilakukan Umar bin Khatab dalam ijtihadnya. Pada masa itu Umar melihat banyak para lelaki yang mempraktekkan nikah mut'ah dengan tanggung jawab yang lemah dan tidak terkontrol. Tidak sedikit anak yang lahir dari pernikahan mut'ah diingkari dan ditelantarkan oleh bapak-bapak mereka. lviii Sehingga dalam kondisi yang seperti ini nikah mut'ah dilarang.

Secara umum Syiah tetap mengizinkan dan membolehkan dilaksanakannya nikah mut'ah di masa kini. Syi'ah membantah pendapat yang mengatakan bahwa nikah mut'ah hanya diberlakukan 
Uswatun Hasanah; Nikah Mut'ah Riwayatumu kini (Tela'ah Tentang Pelaksanaan Sunnah Nikah Mut'ah Melalui Pendekatan Hadits dan Sirah Nabawiyah)

pada saat terjepit dengan menganalogikannya pada kasus kebolehan memakan bangkai dan darah. Beberapa syarat yang kemudian ditetapkan untuk pelaksanaan nikah mut'ah ialah pertama: untuk perempuan yang akan dinikahi secara mut'ah tidak diharuskan muslimah, boleh dari perempuan kitabiyah; Nasrani ataupun Yahudi. Kedua, harus ada perjanjian hitam di atas putih tentang mahar (maskawin) dan adanya batas waktu. Sementara untuk soal wali dan saksi kelompok Syi'ah tidak mewajibkannya. ${ }^{\text {lix }}$ Pendapat mazhab Syi'ah sepertinya memiliki kelemahan dalam metodologi. Karena Syiah yang menggunakan riwayat Ibnu Abbas sebagai dalil untuk mendukung pendapatnya tetapi sesungguhnya Ibnu Abbas sendiri di dalam riwayat yang sama telah menyampaikan tentang pelarangan nikah mut'ah.

Berdasarkan uraian hadishadis dan athar-athar nikah mut'ah yang dirujuk al-Tabatabai secara implisit dan eksplisit ialah mendeskripsikan sikap alTabatabai mengekspresi-kan riwayat-riwayat Ahlu-sunnah dalam kajian tafsirnya. Al-Tabatabai juga mengeksplorasi beberapa riwayat Ahlusunnah yang mentolerir praktek nikah mut'ah di awal Islam dengan legalitas formal dari Nabi saw. Semua hadis ditransmisikan oleh Ibnu Abbas dengan redaksi yang variatif serta adapula riwayat dari Muslim al-Quri. Para kritikus hadis menghukumi kualitas hadis lemah karena simpang siurnya periwayatan. al-Tabatabai tetap meyakini kebenaran hadis dengan merujuk hadis-hadis Syiah yang bersumber dari kitab primernya.

Dalam tafsir al-Mizan alTabatabai mengeksplorasi sebanyak sembilan riwayat imamiyah pada bahthu akhhar rawai dan menghukuminya sebagai hadis mutawatir. Tabatabai mengakui secara mutawatir bahwa nikah mut'ah merupakan warisan Islam sejak awal dan menolak sebagai warisan dari kaum jahiliyah termasuk menolak jika diparalelkan seperti zina sebagaimana yang dipahami oleh sebagian Ahlusunnah.

Al-Nawawi sebagai duta dari golongan Sunni menuturkan tentang siklus haram dan halalnya nikah mut'ah. Legitimasi nikah mut'ah ada pada masa pra perang Khaibar namun pada tahun yang sama nikah mut'ah justru diharamkan. Selanjutnya, pada peristiwa Fath al-Makkah nikah mut'ah sempat dilegalkan kembali kemudian setelah itu untuk selamanya tidak ada lagi pintu masuk guna melakukan akad nikah secara mut'ah ${ }^{1 x}$. Pendek kata, menurut mazhab Sunni, nikah mut'ah hukumnya haram. Pendapat ini didasarkan pula pada hadis Nabi saw berikut: 


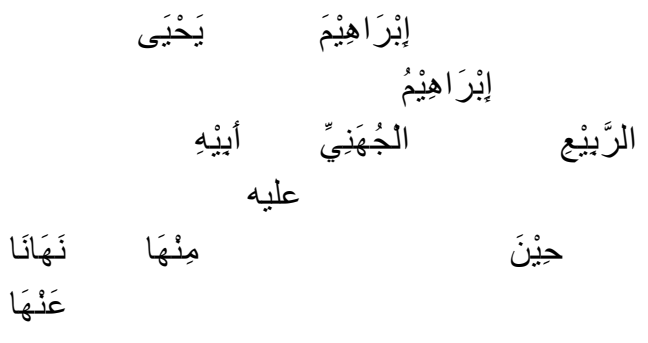

Telah menceritakan kepada kami Ishaq bin Ibrahim telah mengabarkan kepada kami Yahya bin Adam telah menceritakan kepada kami Ibrahim bin Sa'ad dari Abdul Malik bin al-Rabi' bin Sabrah al-Juhani dari ayahya dari kakeknya dia berkata: Rasulullah saw pernah memerintahkan nikah mut'ah pada saat penaklukan kota Makkah dan kami tidak keluar (dari Makkah) melainkan ia (Rasul saw) telah melarangnya (kembali). ${ }^{\text {xi }}$

Dalam sebuah riwayat lbn Hibban $^{\text {lxii }}$ menjelaskan bahwa ketika Nabi saw melihat adanya penderitaan yang dialami kaum perempuan pelaku nikah mut'ah setelah berakhirnya pernikahan kemudian diekspresikan melalui tangisan yang meratap maka segera Nabi saw mengharamkan pelaksanaan nikah mut'ah.

Meskipun Islam memegang prinsip kemudahan dalam pelaksanaan semua syariatnya. Apabila diperhatikan banyak kebaikan bagi para mukallaf yang senantiasa dipertimbangkan ketika pemberlakuan sebuah syariat. Tidak terkecuali dalam sebuah anjuran untuk melaksanakan pernikahan. Ada beberapa alternatif pernikahan yang disyariatkan agama berbeda dalam ketentuan karena disesuaikan dengan kondisi mukallaf. Pada situasi umum misalnya para pemuda bisa melaksanakan pernikahan secara monogami, satu laki-laki untuk satu wanita.

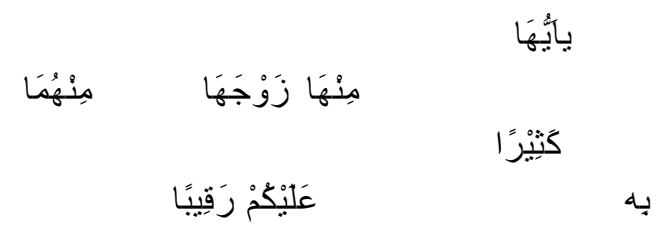

Hai sekalian manusia, bertakwalah kepada Tuhan-mu yang telah menciptakan kamu dari diri yang satu, dan daripadanya Allah menciptakan isterinya; dan daripada keduanya Allah memperkembang biakkan laki-laki dan perempuan yang banyak, dan bertakwalah kepada Allah yang dengan (mempergunakan) namaNya kamu saling meminta satu sama lain, dan (peliharalah) hubungan silaturrahim. sesungguhnya Allah selalu menjaga dan mengawasi kamu. ${ }^{\text {xiii }}$

Akan tetapi khusus bagi para pemuda yang memiliki kondisi tertentu misalnya disebabkan kemauan dan kemampuan berlaku adil bisa saja melakukan pernikahan secara poligami yaitu dengan menikahi beberapa wanita sekaligus dalam waktu yang bersamaan, ${ }^{\mid x i v}$ secara resmi bukan dengan cara mut'ah. 
Uswatun Hasanah; Nikah Mut'ah Riwayatumu kini (Tela'ah Tentang Pelaksanaan Sunnah Nikah Mut'ah Melalui Pendekatan Hadits dan Sirah Nabawiyah)

Dalam firman Allah swt tersebut juga dijelaskan akan hakikat sebuah pernikahan yaitu untuk mencapai tujuan mulia bagi siapa saja yang menjalaninya. Membina rumah tangga yang langgeng, mendapatkan keturunan dan membina hubungan baik di antara kedua keluarga besar. Tujuan ini tentu tidak akan didapat dari sebuah pernikahan secara mut'ah yang memang nihil akan tujuan tersebut. Karena tujuan pernikahan mut'ah tidak lain dari sekedar pelepasan sebuah rasa dahaga sesaat, ketika hilang rasa dahaga maka berakhir pula suatu hubungan.

Apabila pernikahan dianggap sebagai sunnah Rasul saw dan pengamalan separuh agamalkv maka akan lebih memotivasi untuk senantiasa memelihara dan menjaga keberlangsungannya. Karena tanggung jawab berkeluarga, sebagai seorang suami, istri ataupun anak-anak tidak hanya dibatasi dalam kurun waktu tertentu saja tetapi akan terus berlangsung dan tetap akan dipertanggung jawabkan sampai hari kiamat. ${ }^{\text {Ixi Seandainya nikah }}$ mut'ah adalah sebuah solusi bagi pemuda yang berkeinginan menikah namun belum memiliki kemampuan tentu Rasul saw tidak memerintahkan padanya untuk berpuasa tetapi pastinya akan menganjurkan kepadanya melakukan nikah mut'ah.

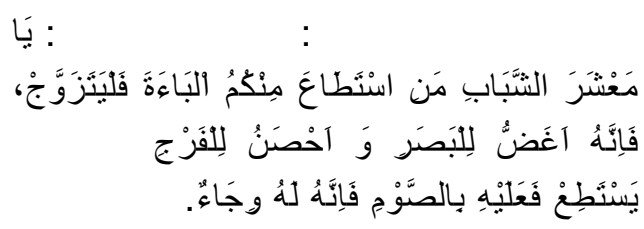

Dari Ibnu Mas'ud, ia berkata: Rasulullah saw bersabda, "Hai para pemuda,barangsiapa di antara kamu yang sudah mampu menikah, maka nikahlah, karena sesungguhnya nikah itu lebih dapat menundukkan pandangan dan lebih dapat menjaga kemaluan. Dan barangsiapa yang belum mampu, maka hendaklah ia berpuasa, karena berpuasa itu baginya (menjadi) pengekang syahwat" Ixvii Akhirnya hal yang perlu dicermati dari sebuah sirah nabawiyah dan hadis-hadis Rasulullah saw bahwa Muhammad saw sebagai nabi, rasul dan teladan ummat hingga akhir zaman tidak pernah merekomendasi sebuah sunnah pun kecuali dialah sebagai orang pertama yang melakukannya. Akan halnya pelaksanaan nikah mut'ah Rasul saw tidak pernah melakukannya sampai akhir hayatnya. Ini semakin memperkuat keyakinan bahwa nikah mut'ah bukanlah sunnah yang baik untuk diikuti.

\section{B. PENUTUP}

Dari informasi hadis dan sirah nabawiyyah diyakini bahwa keberadaan nikah mut'ah sulit 
terbantahkan. Terlepas dari sahih atau tidaknya sebuah riwayat ataupun beragamnya informasi mengenai kapan dibolehkan dan dilarangnya nikah mut'ah, Banyaknya riwayat yang menceritakan tentang nikah mut'ah cukup memberi keyakinan akan keberadaannya. Juga banyaknya sahabat yang mempraktekkan nikah mut'ah baik pada masa Rasul saw masih hidup di tengah-tengah sahabatnya atau setelahnya.

Meskipun Rasul saw tidak melakukan nikah mut'ah namun disepakati bahwa hadis tidak hanya prilaku Nabi saw tetapi juga perkataan dan taqrirnya atas prilaku para sahabat di sekitarnya. Sebagaimana yang diketahui juga dari hadis dan sirah nabawiyyah bahwa Rasul saw memberikan respon, baik dalam bentuk legitimasi ataupun pelarangan terhadap prilaku nikah mut'ah para sahabatnya.

Hal yang perlu dicermati dari sebuah sirah nabawiyah dan hadishadis Rasulullah saw bahwa Muhammad saw sebagai nabi, rasul dan teladan satu-satunya bagi ummat hingga akhir zaman tidak pernah merekomendasi sebuah sunnah pun kecuali dialah sebagai orang pertama yang melakukannya. Akan halnya pelaksanaan nikah mut'ah Rasul saw tidak pernah melakukannya sampai akhir hayatnya. Info ini cukup memberi keyakinan bahwa nikah mut'ah bukanlah sunnah yang baik untuk diikuti.

\section{Daftar Pustaka}

Abu Dawud Sulayman Ibn alAth'ath al-Sijistaniy, Sunan Abu Dawud, Mesir: Dar alMishriyyah al-Lananiyyah, 1988.

Al-Asqalaniy, Ahmad bin 'Ali ibn Hajar al-Asqalani, Tahdhib alTahdhib, India: Majlis Dairat al-Ma'arif al-Nizamiyah, 132,5 Ahmad bin Ali bin Haajar alAsqalani, Bulugh al-Maram min Adilati al-Ahkam

Al-Baghdadi, Alauddin Ali bin Muhammad bin Ibrahim (alHazin), Lubab al-Ta'wil fi Ma'ani al-Tanzil, Beirut: Dar al-Fikr, 1979/ 1399

Al-Baghdadi, Alauddin Ali bin Muhammad bin Ibrahim alBaghdadi (al-Hazin), Lubab al-Ta'wil fi Ma'ani al-Tanzil, Beirut: Dar al-Fikr, 1979/ 1399

Al-Baqi, Muhammad Fu'ad Abdu alBaqi, al-Mu'jam al-Mufahras li Alfaz al-Qur'an al-Karim, Istambul: al-Maktabat alIslamiyah, 1984.

Al-Baihaqi, Sunan al-Kubra, : Dar al-Fikr, t.th.

Al-Baqi, Muhammad Fu'ad Abdu, al-Mu'jam al-Mufahras li Alfaz al-Qur'an al-Karim, Istambul: al-Maktabat al-Islamiyah, 1984

Al-Bukhari, Abu Abd Allah 
Uswatun Hasanah; Nikah Mut'ah Riwayatumu kini (Tela'ah Tentang Pelaksanaan Sunnah Nikah Mut'ah Melalui Pendekatan Hadits dan Sirah Nabawiyah)

Muhammad bin Ismail, Sahih Bukhari, Beirut: Dar al-Fikr

Al-Nasai, Abu Abd al-Rah\}man Ahmad bin Syu'aib,Sunan alNasa'i, Beirut: Dar al-Fikr

Al-San'ani, Abu Bakr ibn Hamman Abd al-Razaq al-San'ani, Musannaf , Majlis al-IImi

Al-Shaukani, Muh\{ammad bin 'Ali bin Muhammad, Nailu alAutar, Beirut: Dar al-Fikr

Al-Suyuthi, al-Dur al-Manthur, Kairo: Sar al-Salam, 1994

Al-Tabatabai, Al-Sayyid Muhammad Husain alTabataba'i, al-Qur'an fi alIslam, Iran: Markaz I'lam alDzikra al-Khamisah li intishar al-Sawrat al-Islamiyah, 1404 $\mathrm{H}$

Al-Tabari, Tafsir al-Tabari, Beirut: Dar al-Ma'rifah, t.th.

Al-Turmudzi, Abu Isa Muhammad bin 'Isa, Sunan al-Turmudzi, Beirut: Dar al-Fikr, 1400

Ibnu Abi Hatim, Muhammad Abdurrahman, Tafsir Ibnu Abi Hatim (al-Maktabah al'Asriyah, [t.th.]), juz III, 919

Ibn Hanbal, Abu Abd Allah Ahmad bin H\}anbal, Musnad Ahmad bin Hanbal, Beirut: Dar alMaktab al-Islami, 1379

Ibn Hibban, Sahih Ibn Hibban, Beirut: Dar al-Maktab alIslami, t.th.

Ibn Kathir, Tafsir al-Qur'an al-'Azim, t.p: Dar al-Tayyibah, 1420

Ibn Majah, Abu Abd Allah Muhammad bin Yazid, Sunan Ibn Majah, Beirut: Dar al-Fikr

Ibn Manzur, Lisan al-Arab, Beirut: Dar al-Fikr, 2002/1423.

Malik bin Anas, Abu Abd Allah, Muwatha' Malik, t.tp. : Dar alSha'b, t.th.

Muslim, Abu Husayn Muslim bin alHajjaj, Sahih Muslim, Beirut: Dar al-Fikr, 1985.

i Bandingkan dengan Abu Abd Allah Muhammad bin Ismail, Sahih Bukhari (Beirut: Dar al-Fikr, [t.th.]), Juz III, 26. Al-Baihaqi, Sunan al-Kubra (Beirut: Dar al-Fikr, [t.th.]), juz. VII, 204.

iil bn Hajar, Tahdhib-Tahdhib, Juz VII, 99

iii Ibn Hibban, Sahih Ibn Hibban, Juz IX, 454.

iv Ibn Hajar, Tahdhib-Tahdhib, Juz II, 309. Lihat juga Abu Abd Allah Muhammad bin Ahmad alDzahabi, Mizan al-l'tidal fi Naqd al-Rijal ([t.p]: [t.tp], 1963), Cet.I, Juz II, 680-681.

v Ibn Hajar, Tahdhib-Tahdhib, Juz VI, 487

vi Ibn Hajar, Tahdhib-Tahdhib, Juz III, 340-341

vii Ibn Hajar al-Asqalani, Fath al-Bar, Juz IX, 171-172. Lihat juga al-Bukhari, Sahih al-Bukhari, Juz III, 27.

viii al-Tabatabai, al-Mizan, Juz IV, 298. al-Bukhari, Sahih alBukhari, Juz III, 26.

ixLihat Muslim, Sahih Muslim, Juz 
IV, 55. Bandingkan alTabatabai, al-Mizan, Jilid IV, 304.

xLihat Ibn Hajar, Fath al-Bar, Juz III, 339. Abu Dawud, Sunan Abu Dawud, Juz II, 186. Bandingkan al-Baihaqi, Sunan al-Baihaqi, Juz VII, 201.

xiLihat Ibn Hajar, Fath al-Bar, Juz VII, 204. al-Tabatabai, alMizan, Jilid 4, 299.

xiilbn Hajar al-Asqalani, Tahdhib alTahdhib, Juz III, 309. lihat juga al-Dzahabi, Mizan I'tidal, Juz II, 680-681.

xiiiAl-Turmudzi, Sunan al-Turmudzi, III, 430.

xivLihat kembali al-Baihaqi, Sunan al-Kubra, 21.Ahmad ibn Hanbal, Musnad Ahmad ibn Hanbal , Juz VI, 348.

xvLihat Muhammad bin 'Ali bin Muh\}ammad al-Shaukani, Nailu al-Autar (Beirut: Dar alFikr, 1393), jilid VI, 268.

xviLihat Al-Tabatabai, al-Mizan, jilid IV, 293-294.

xviiLihat Ibn Hajar al-Asqalani, Fath al-Bari, jilid VII, 700.

xviiiLihat Ahmad bin Hanbal, Musnad Ahmad bin Hanbal, jilid III, 405.

xixAl-Nasa'i, Sunan al-Nasa'i, juz IV, 126.

xxAI-Tabatabai, al-Mizan, jilid IV, 299 xxiAl-Tabatabai, al-Mizan, jilid IV, 299

xxiiAl-qira'ah adalah kumpulan permasalahan yang berkaitan dengan perbedaan penukilan kitab Allah baik dari aspek pengucapan bahasa, i'rab, ithbat (penetapan), fasl dan wasal, sebagaimana penukilan secara sima'un yang terdengar. Lihat Ibn Faris, Mu'jam Maqayis alLughah (Mesir: Maktabat alKhanji, 1402 H/ 1981 M), juz V, 79. Ibn Mandzur, Lisan alArab (Mesir: al-Dar alMishriyyah, [t.th.]), Juz I, 128. Muhammad bin 'Umar bin Salim Bazamul, al-Qur'an wa Atharuh fi al-Tafsir wa alAhkam (Riyad: Dar al-Hijrah, 1996/ 1417), cet I, 179-112.

xxiiiAbu Isa Muhammad bin 'Isa alTurmudzi, Sunan alTurmudzi, kitab al-nikah, bab Tahrim Nikah al-Mut'ah, Juz III, 430 .

xxivlbnu Abi Hatim, Muhammad Abdurrahman, Tafsir Ibnu Abi Hatim (al-Maktabah al'Asriyah, [t.th.]), juz III, 919. Lihat juga Tabataba'i, alMizan, jilid IV, 297.

xxvAl-Tha'labi menjelaskan bahwa maksud perkataan tersebut adalah: tidak ada yang memberikan rukhsaah nikah mut'ah kecuali Imran bin alHusain, Abdullah binAbbas dan sebagian sahabat (muridnya) termasuk kelompok Ahlulbait. Lihat alTabatabai, al-Mizan,juz I, 583.

xxviAl-Tabari, Tafsir al-Tabari (Beirut: Dar al-Ma'rifah, 
Uswatun Hasanah; Nikah Mut'ah Riwayatumu kini (Tela'ah Tentang Pelaksanaan Sunnah Nikah Mut'ah Melalui Pendekatan Hadits dan Sirah Nabawiyah)

\footnotetext{
[t.th.]), juz VII, 178

xxviiAl-Tabari, Tafsir al-Tabari, Juz $\mathrm{VI}, 179$.

xxviiiAl-Tabari, Tafsir al-Tabari, Juz VI, 179.

xxixAl-Tabari, Tafsir al-Tabari, Juz VIII, 172

xxxAhmad bin Ali bin Jajar alAsqalani, Tahdhib al-Tahdhib (India: Majlis Da'irat al-Ma'arif al-Nizammiyah, $1325 \mathrm{H}$ ), Juz III, 500

xxxiAhmad bin Ali bin Jajar alAsqalani, Tahdhib alTahdhib , Juz III, 595

xxxiiAhmad bin Ali bin Jajar alAsqalani, Tahdhib alTahdhib , 561

xxxiiiAhmad bin Ali bin Jajar alAsqalani, Tahdhib alTahdhib , 561 dan 299

xxxivAhmad bin Ali bin Jajar alAsqalani, Tahdhib alTahdhib , 150

xxxvlbnu Kathir, Tafsir Ibnu Kathir, jilid I, 474.

xxxviMenurut mayoritas ulama dan para Qurra' bahwa qira'ah Ibnu Mas'ud dan Ubay bin Ka'ab kontradiksi dengan qira'ah yang masyhur, baik qira'ah sab'ah maupun 'asharah seperti yang tertera pada mushaf usmani yaitu pada surat al-Nisa' (5): 24.

xxxviiMengenai lafal ini, terdapat di dalam al-Qur'an sebanyak delapan belas kali terulang pada surat dan ayat yang berbeda-beda baik Makiyah maupun Madaniyah. Lihat
}

Muhammad Fuad Abdul Baqi, al-Mu'jam al-Mufahras (Bandung: Maktabah Dahlan, [t.th.]), 19

xxxviiiAl-Tabari, Tafsir al-Tabari, Juz VI, 178.

xxxixAl-Tabari, Tafsir al-T \}abari, Juz VI, 176.

xIAhmad bin Ali bin Jajar al-Asqalani, Bulugh al-Maram min Adilati al-Ahkam (Beirut: Dar al-Fikr, 1398 H), Juz I, 352.

xlilbn Manzur, Lisan al-Arab (Beirut: Dar al-Fikr, 2002/ 1423), juz VIII, 328. Muhammad Fu'ad Abdu al-Baqi, al-Mu'jam alMufahras li Alfaz al-Qur'an alKarim (Istambul: al-Maktabat al-Islamiyah, 1984), 833-834. Lihat juga Q.S. Hud (11): 3,30, al-Hijr (15): 3, Muh\}ammad (47): 12, Ibrahim (14): 30 dan alMursalat (77): 46

xliiLihat Q.S. al-An'am (6): 128, alAhqaf (46): 20, dan alTaubah (9): 69

xliiiQ.S. al-Nisa' (4): 4

xlivQ.S al-Nisa' (4): 4 dan 25.

xIvQ.S. al-Baqarah (2): 236.

xlviQ.S. al-Nisa' (4): 225

xIviiQ.S. al-Nur (24): 33

xlviiiAhmad bin Ali bin Jajar alAsqalani, Bulugh al-Maram min Adilati al-Ahkam, Juz I, 352. Lihat kembali footnote 58.

xlixAlauddin Ali bin Muhammad bin Ibrahim al-Baghdadi (alHazin), Lubab al-Ta'wil fi Ma'ani al-Tanzil (Beirut: Dar 
al-Fikr, 1979/ 1399), juz I, 506

IAI-Tabatabai, al-Mizan, jilid IV, 303

liAl-Tabatabai, al-Mizan, jilid IV, 302303

liiAl-Tabatabai, al-Mizan, jilid IV, 296

liiiAl-Tabatabai, al-Mizan, jilid IV, 296-297

livAl-Tabatabai, al-Mizan, jilid IV, 303

IvLihat kembali Abu Dawud, Sunan Abu Dawud, Juz II, 168.

IviLihat Abu Dawud, Sunana Abu Dawud, Juz II, 168

Iviilbn Kathir, Tafsir al-Qur'an al'Azim ([t.p]: Dar al-Tayyibah, 1420), Juz II, 243-244.

IviiiAl-Tabatabai, al-Mizan, jilid IV, 297

lixAI-Tabatabai, al-Mizan, jilid IV, 298

IxAI-Nawawi sebagaimana dikutip oleh Al-Tabatabai, al-Mizan, jilid IV, 299

IxiAl-Hazin, Lubab al-Ta'wil fi Ma'ani al-Tanzil, 507

IxiiLihat kembali Ibn Hibban, Sahih Ibn Hibban, Juz IX, 456.

IxiiiQ.S. al-Nisa (4): 1

IxivQ.S. al-Nisa (4): 3

IxvLihat hadis-hadis tentang anjuran menikah seperti riwayat Muslim, al-Turmudzi, Abu Dawud, al-Nasa'i dari Aisyah tentang anjuran menikah.

IxviQ.S. al-Nisa (4): 34 lihat juga hadis riwayat al-Bukhari dan Muslim tentang pertanggung jawaban suami atas istri dan anak-anak, juga tanggung jawab istri terhadap harta suaminya dan tanggung jawab anak terhadap orangtuanya.

IxviiH.R. Jama'ah 
Uswatun Hasanah; Nikah Mut'ah Riwayatumu kini (Tela'ah Tentang Pelaksanaan Sunnah Nikah Mut'ah Melalui Pendekatan Hadits dan Sirah Nabawiyah) 